\title{
What Keeps Students from Driving under the I nfluence of Alcohol and Prescription Drugs? The I mpact of Legitimacy of the Law, Prudent Behaviour and Perceived Dangerousness
}

\author{
STEFAN MACHURA* \\ SUNITA MATHARU* \\ FAYE MEPHAM \\ SARAH LEANNE SMITH \\ J ONATHAN ASTON
}

Machura, S., Matharu, S., Mepham, F., Smith, S.L., and Aston, J., 2019. What Keeps Students from Driving under the Influence of Alcohol and Prescription Drugs? The Impact of Legitimacy of the Law, Prudent Behaviour and Perceived Dangerousness. Received 13 January 2019, Accepted 10 September 2019. Oñati Socio-Legal Series [online], 9(6), 10521077. Available from: https://doi.org/10.35295/osls.iisl/0000-0000-0000-1076

\begin{abstract}
Driving under alcohol or while under the influence of a medication that impedes the ability to control a car are punishable offenses. The study asks if the perceived legitimacy of law, the perceived dangers of driving, including detection by the police, and the individual inclination to engage in risky and imprudent behaviour influence the likelihood of committing those offenses. At a British university, 337 students took part in a questionnaire study. The results show that students are less inclined to drive under alcohol than under medication. Both are variously influenced by practical circumstances like the frequency of driving, of drinking and the actual taking of such medication, even pressures to drive regardless. Driving under medication is also related to legitimacy of law. The difference may come from the absence of a public narrative for driving under medication: some students fall back to their attitude to the law.
\end{abstract}

\section{Key words}

Legitimacy of law; driving under alcohol; driving under medication; perceived risk; imprudent behaviour

\section{Resumen}

Conducir bajo los efectos del alcohol o de algún medicamento que obstaculice la capacidad de conducir un automóvil son delitos punibles. Este estudio se pregunta si

The authors wish to thank Prithvi Reddy Keesara for collaboration in conducting the study as well as the following Bangor University staff for allowing to distribute questionnaires in their classes: Annika Beelitz, Edward J ones, Ann MacLaren, Marie Parker, Marco Pelliccia, Osian Rees, Roger Slack and Julia Wardhaugh. Finally, the authors would like to thank two anonymous reviewers for their suggestions.

* Stefan Machura is Professor of Criminology and Criminal Justice at the School of History, Philosophy and Social Sciences, Bangor University, UK. Contact details: School of History, Philosophy and Social Sciences, Bangor University, Bangor. Gwynedd LL57 2DG, United Kingdom. Email address: s.machura@bangor.ac.uk ORCID: http://orcid.org/0000-0001-7619-2529

* Sunita Matharu, Sarah Leanne Smith and Jonathan Aston took part in the MA module Applied Social Research, Faye Mepham as undergraduate student intern.

\section{(cc) EY-NC-No}

Oñati International Institute for the Sociology of Law Antigua Universidad s/n - Apdo.28 20560 Oñati - Gipuzkoa - Spain 
la legitimidad percibida de la ley, los peligros percibidos de conducir (incluida la detección por parte de la policía) y la inclinación a mantener conductas arriesgadas e imprudentes influyen en la probabilidad de cometer dichos delitos. En una universidad británica, 337 estudiantes respondieron en un cuestionario. Los resultados muestran que los estudiantes son menos propensos a conducir bajo los efectos del alcohol que de medicamentos. Ambos casos están influidos por circunstancias prácticas, como la frecuencia de la conducción, de beber y de tomar dicho medicamento, incluso presiones para conducir en cualquier caso. Conducir bajo los efectos de medicamentos está relacionado con la legitimidad de la ley. La diferencia puede radicar en la ausencia de una narrativa pública sobre conducir bajo los efectos de medicamentos: algunos estudiantes se amparan en su actitud hacia la ley.

\section{Palabras clave}

Legitimidad de la ley; conducir bajo los efectos del alcohol; conducir bajo los efectos de medicamentos; riesgo percibido; comportamiento imprudente 


\section{Table of contents / Índice}

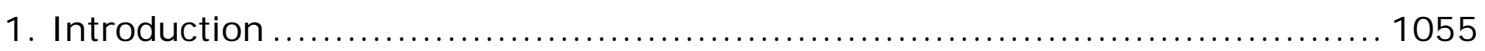

1.1. Explanations for (not) driving under the influence ....................... 1056

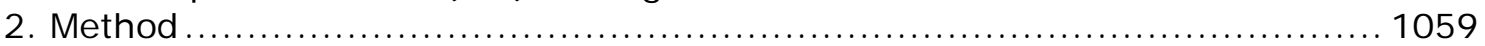

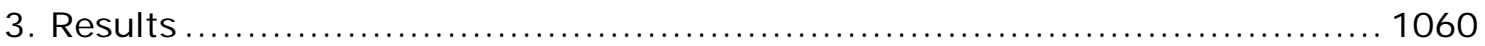

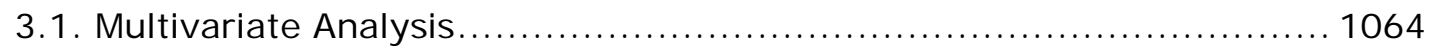

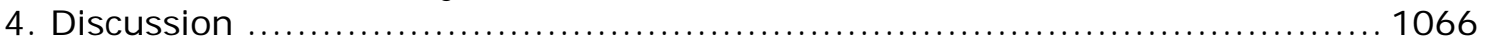

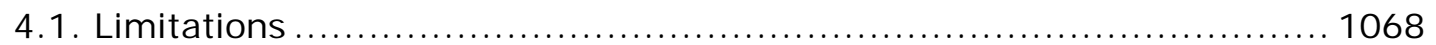

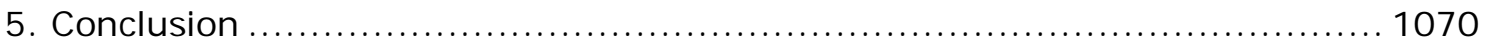

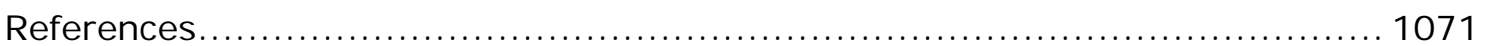

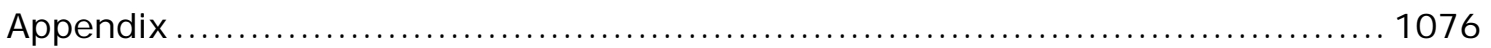




\section{I ntroduction}

Technical innovations have made driving safer for drivers and others who may be potentially involved in an accident, but the risk of human error remains. One of the dangers still prevalent is drivers being under the influence of a substance affecting their ability to safely control their vehicle. Two substances that are widely used are alcohol and prescribed medication (especially tranquilizers, antihistamines, and antidepressants; see Moskowitz 2009, p. 120); all come with a warning not to drive. The seriousness of the offence has triggered the threat of criminal punishment, with the United Kingdom being just one example. But, while there have been decades of campaigning to warn people of the dangers of drink driving, and of the legal consequences, there is little effort in relation to medication that affects the ability to control a car. This study tries to understand the causes of peoples' attitude to driving under the influence of those two types of substances with a special emphasis on people's attitude to law in general. Moreover, the perceived legitimacy of law is compared to other factors, including the likelihood to be stopped by the police. Young people form a special group of concern when it comes to road safety and the present study uses a student sample.

It was estimated that in 2015, about 220 fatalities in Great Britain resulted from drink driving, as well as 1,170 serious and 7,100 "slight" injuries (Department for Transport 2017). Drink driving is one of several different reasons for arrest when the perpetrator is under the influence of alcohol. The law on drink driving in the UK has developed in steps, starting already in 1872 with concerns about carriages and steam engines, and in reaction to public debates and campaigns (Yeomans 2014, pp. 133, 150-151, 154). Penalties in England, Wales and Northern Ireland for this crime range from three months imprisonment and a fine of up to $f 2,500$, to 14 years imprisonment, a ban from driving for two years or an unlimited fine. There are secondary consequences such as the rising price of car insurance and being placed on a High Risk Offenders list (Government Digital Service 2018a). Scotland has lower alcohol limits (Government Digital Service 2019) and a minimum disqualification from

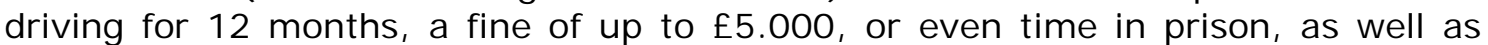
forfeiture and destruction of the motor vehicle (Unlock the Law 2017).

Furthermore, medication has been known to affect driving ability; the use and abuse of legal prescription drugs that impair driver's abilities contribute to fatal and serious accidents (DuPont 2010, p. 129, Hamnett and Poulsen 2018, pp. 1461-1462). Drivers can receive medication from their doctors and disregard warnings, but there is also the danger of abusing drugs. Prescription drug abuse may well have become more widespread, as indicated by data on drug driving fatalities by Hamnett and Poulsen (2018, p. 1463) for Scotland, and by Schroeder and Ford (2012, pp. 5, 8) for the USA, where the medicines are obtained from sources like family members or the internet. The same sources may be used in the UK to obtain drugs, in addition to legitimate channels. Although it is not as publicised as drink driving, operating a car under the influence of medication that impairs one's ability to drive is punishable by law in the United Kingdom. Penalties for this offence consist of a minimum one-year driving ban, an unlimited fine, up to six months in prison and a criminal record. If a fatality is caused due to dangerous driving under the influence of drugs, the offender could receive up to 14 years in prison (Government Digital Service 2018b).

Like the UK, other countries have long established measures to address drink driving, and awareness is slowly increasing about driving under the influence of medication that impairs the ability to safely control a vehicle. While there is an impressive international literature about driving under the influence of alcohol, fewer studies to date have turned to the issue of medication. There especially is a lack of works relating the two and the present article offers such a comparison. It introduces criminological, psychological and socio-legal explanations for the inclination to engage in these two risky activities. By focusing on inclinations, we pay attention to the possibility that many individuals have not yet committed these offences, but they 
may be exposed to situations in which they are tempted to do so. Moreover, an individual driver may be under the influence of a substance and they have to decide how to react or, passengers have to decide whether or not to travel with an intoxicated driver. The more unlikely they see themselves engaging in such activities, the more likely it might be that they resist should the situation come up.

\subsection{Explanations for (not) driving under the influence}

Theory and research suggest a number of explanations for why people may avoid driving under the influence of alcohol or medication; for example, they may know they must obey the law. According to Max Weber (1968, pp. 31, 36, 37), a social order, such as a law being "legitimate", has a probability of being followed if it is seen as "binding" or "exemplary". In a Weberian perspective, citizens may be convinced of the content of the law, they may think it has been issued by a legitimate authority using proper law-making procedure, or they at least are aware that society expects such laws to be observed. In the course of "legitimation by procedure" (Luhmann 1975, pp. 188, 193, 195, 200, Machura 1997), parliament and government are perceived to process different views and sufficient information when drafting a law. It is then expected that citizens keep the resulting norm.

Legitimacy of rules becomes important in situations in which they are inconvenient or where there is an interest to ignore them. Drivers easily find themselves in such circumstances. Then, traffic laws may be seen as impractical or a nuisance. For example, a survey revealed that $27 \%$ of German drivers interviewed indicated feeling annoyed if other drivers consequently stick to the traffic rules (Eicher 2016, p. 14). The perceived reasonableness of norms in interaction with the situation confronted with can influence how people behave (Feest 1968, pp. 457-58); drivers may speed through a red light when no one else is to be seen at a pedestrian crossing. Still, when it comes to laws, there may be an element of mutual obligation, a feeling that if one expects others to generally obey rules, one should also do so.

A personal inclination to engage in imprudent behaviour may also facilitate driving while in an unfit state. It indicates a lack of self-regulation as character trait, an area widely discussed in psychology and criminology (recent overview: Schulz 2017). A tendency to act imprudently would manifest itself widely in an individual's life, permeating many aspects of it. Impulsivity and risk seeking are part of "low selfcontrol" suggest Grasmick, Tittle, Bursik and Arneklev (1993, p. 14): the individuals would, for example, "act (...) without stopping to think", be interested in short term rather than long term outcomes, or seek "excitement and adventure" rather than security. Not being able to reign in one's impulses and to rationally approach risktaking are therefore related. Alcohol and medication use that affects reasonable judgment can lead to an individual being involved in more actions that are imprudent. The consumption of alcohol itself can be considered risk-taking behaviour, as can be the use of illegally obtained medicine, or of medicines with strong side-effects. They require a judgement of benefits and risks, certainly in relation to operating a vehicle.

Alcohol can be bought legally within the UK from the age of 18 and above. Amongst its negative side effects is a reduced ability to fairly and consciously make clear, beneficial decisions. Intoxicated drinkers react to the most salient immediate cues rather than considering contexts and consequences, or ponder a more realistic selfevaluation, that would normally inhibit ill-advised behaviour. It causes "alcohol myopia" (Steele and J osephs 1990, pp. 923-924, 927-928). Those who have drunk even a small quantity may have diminished capability to weigh up a decision. They are less likely to see the severity of a consequence and more willing to see the positives of a reward (George et al. 2005, p. 168, English students). Therefore, they may be more likely to take risks that lead to a criminal act (Dawkins 1997, p. 401, US juvenile training school, Carpenter 2005, p. 270, FBI data). College students consuming alcohol excessively, especially males, tend to be more sensation seeking and impulsive (Brennan et al. 1986, pp. 457, 469, review of mainly of US studies). 
Intoxicated students in Canada were more likely than sober students to drive when confronted with a reason to drive (MacDonald et al. 1995, p. 982). The motive "to get there quicker" was found related to self-reported drink driving by young Australian male and female drivers (Hatfield and Fernandes 2009, p. 30). In a Canadian study, younger male drivers were more optimistic about avoiding negative consequences (Gosselin et al. 2010, p. 738).

Being detected by police has been called "secondary risk" in a recent study (Elias et al. 2017, p. 189). Arab and Israeli youth who expected it could happen to them have been less likely to drink drive (Elias et al. 2017). Yet, drink drivers may believe that they can avoid police controls (Beck 1981, pp. 383-84). Indeed, it is unlikely that drink drivers are detected by police (Stewart and Sweedler 1997, pp. 130-131, Moskowitz 2009, pp. 110). For driving under the influence of medication, detection is even more unlikely (Moskowitz 2009, pp. 120-121).

A gender difference is well established when it comes to alcohol consumption and is quite universal. ${ }^{1}$ However, a more recent analysis based on the Health Survey for England showed that about $40 \%$ of male and of female students reported to engage in "binge drinking", and $4.7 \%$ of the males and $3.5 \%$ of the females drank alcohol daily (Castillo et al. 2017, p. 35). Nevertheless, an analysis of drink drivers among all police-recorded collisions between 2011 and 2015 in the UK identified young males as most frequently involved (Owen et al. 2019, pp. 456-458). In a broader metaanalysis involving 150 studies, presumably mostly US, Byrnes, Miller and Schafer (1999) compared male and female's likelihood of taking risks, including in relation to addictive behaviours and to driving. They found that males showed a higher level of risk taking behaviours, ${ }^{2}$ "even when it was clear that it was a bad idea to take a risk (...) the opposite was true for women and girls" (Byrnes et al. 1999, p. 378). A Turkish study found that male students were ten times more likely to drive cars while drunk than their female counterparts (Ozascilar 2010, p. 62). For the UK, it is reported that 17- to 24-year old drivers form seven percent of licence holders but "are involved in a quarter of crashes leading to deaths or serious injuries", while young men were "almost four times more likely than women to be killed or seriously injured" (Paton 2019, 1).

Younger age groups are known to be more likely to take risks, partially as they focus more on potential gains than on threatening consequences (Gardner and Steinberg 2005 , p. 629, for a US sample). Statistics show that drivers under 40 years of age are more involved in drink-driving accidents in Great Britain (Department for Transport 2015). They may not have formed a moral opinion on driving under the influence or may have little responsibility; adverse consequences therefore have more minimal effect. Previous literature shows that university students are more likely to drive under the influence of alcohol if they estimate the risk of negative consequences for themselves to be low (Fernandes et al. 2010, pp. 192-193 on Australian students; for male US students: Rolison and Scherman 2003, pp. 699701). Other evidence even points at the possibility that some, especially young males, seek out risks for excitement and are then more likely to engage in drink driving and speeding, on top of factors like giving in to social pressure more easily (Hatfield and Fernandes 2009, p. 30 on Australia). Another pattern is that young drivers may believe that bad things are less likely to happen to themselves (Hatfield and Fernandes 2009, pp. 30,32). While drivers generally overestimate their abilities according to a Canadian study, young males exhibit this trade more so than young females (Gosselin et al. 2010, pp. 739-740).

Icek Ajzen's (1991) Theory of Planned Behaviour (TPB) has guided a range of studies on driving under alcohol. The TPB draws on a link between intention and behaviour:

\footnotetext{
${ }^{1}$ E.g. for Russia: Botchkovar and Broidy 2012, p. 370, for Germany: Frankfurter Allgemeine Zeitung 2016, for Spain: Gonzálvez et al. 2015 finding for males "higher levels of alcohol and other drug use".

${ }^{2}$ Byrnes et al. 1999, pp. 372, 377, see also Rolison and Scherman 2003, p. 701 for US students; Potard et al. 2018, p. 40 for drink driving in France.
} 
It explains the former with an individual's "belief about the normative expectations of others", beliefs about the consequences of the behaviour and perceived control over the behaviour (Ajzen 2002, p. 107). How many of these three factors apply and to what degree they contribute to intentions, may depend on the behaviours and situations (Ajzen 1991, p. 188). In relation to drink driving, several studies including students and young people have supported Ajzen's model. They include Chan, Wu and Hung (2010) for Macao/China, adding irrational beliefs in personal invulnerability to the TPB model. Different from other empirical studies, they suggest an indirect influence of subjective norms via perceived behavioural control and attitudes to drink driving on the behaviour. Subjective norms and attitudes predicted drink driving via the intention to do so among Spanish college students in the survey by Gonzálvez and her team (2015). Moan and Rise (2011) presented a study conducted in Norway. They included further norm elements on top of the TPB model's "subjective norm": "descriptive norm", if friends would drink drive in the same situation, or if they would agree to do so, and "moral norm", aiming at the perception that it is morally wrong, at feelings of guilt and at having a bad conscience (Moan and Rise 2011, pp. 13801382). The TPB concept was supplemented by the individual willingness to drink drive by Rivis, Abraham and Snook (2011) for a study in England, and by Potard and her team (2018) for one in France. The latter also emphasized an influence of past experiences that have turned into behavioural habits (Potard et al. 2018, pp.42-43). Drowsiness can be one consequence of driving under medication. Another study of dangerous driver behaviour also combining the TPB approach with willingness, was reported by Lee, Geiger-Brown and Beck (2016) for US students in relation to drowsy driving. A meta-study of research in the wider field of consumer behaviour concluded that two of the three elements - attitudes and perceived behavioural control highlighted by the TPB seem to apply universally, but not "subjective norm" (Hassan et al. 2016). We are testing a different perspective to Ajzen's, a socio-legal rather than a psychological, highlighting especially the legitimacy of law as a key factor. Legitimacy of law is also a more specific concept than "subjective norm" that better reflects the ultimate authority of the modern state demanding behaviour even where the individual disagrees.

Driving under alcohol and medication which affects the ability to control a car endanger lives on the roads and are punishable by law. Young people are likely to commit these offences; therefore, a student sample was chosen to test hypotheses about the antecedents of such offences. The focus of the study reported here is on how perceived legitimacy of the law, inclination to engage in imprudent and risky activities and perceived dangerousness influences this behaviour. Students feeling obliged to obey laws are assumed to be less likely to drink drive or drive under a medication that affects their ability. Perceived hazards, such as the likelihood to be stopped by police, or assumed dangerousness of driving generally, may inhibit people from making the wrong choices. Individuals with responsibility to care for others may be more reluctant to engage in dangerous activity for fear of consequences, such as no longer being able to help e.g. by driving children or older relatives. If individuals are prone to engage in risky and imprudent behaviour, they will more easily engage in illicit actions. Those three main hypotheses related to legitimacy of law, perceived dangerousness and inclination towards imprudent behaviour are tested against several further factors which may have an effect. Students driving more often, drinking alcohol and taking medication that can affect driving more frequently, or people living rurally where there often is no alternative to cars, ${ }^{3}$ may be more inclined to drive under alcohol and medication. Females are expected to be less prepared to commit those offenses. The same is expected for age, with older people being more careful, although a student sample where people above the age of 25 are a minority may not allow this effect to be analysed sufficiently. There may also be variation across nationality, as students from different countries may have been exposed to

${ }^{3}$ According to UK statistics, crashes due to drink driving are more frequent in rural than urban areas (Owen et al. 2019, p. 456). 
different levels of road safety campaigning. However, considering the practical nature of traffic laws, again this may not play out fully.

\section{Method}

The present study, conducted from January to March 2016, used an opportunity sample of undergraduate students at Bangor University (Wales, United Kingdom). Bangor is a small city located in a predominantly rural environment, allowing for a test of a possible rural-urban effect. Like other UK universities, Bangor has attracted many international students, with Chinese forming the largest segment. A questionnaire (Appendix) was filled out in class on paper or online by 337 students in first, second and third year, studying Social Sciences, Law, or Business. In the busy classrooms before the delayed start of lectures it was difficult to establish the actual return rate. In addition, students had the option to fill in the questionnaire online and they may have done so at a later point in time. However, a return rate of $70 \%$ appears as a conservative estimate. Respondents received a participant information sheet that outlined the purpose of the study and emphasized aspects of data protection and voluntariness of taking part.

The project complies with the ethics guidelines of the British Society of Criminology and of Bangor University. It was approved by the Ethics Committee of the College of Business, Law, Education and Social Sciences, Bangor University.

The respondents were asked to imagine the likelihood to drive a car under the influence of "a couple of alcoholic drinks", or when taking medication where they are not advised to drive for two situations; needing to get home or to work, respectively. Lower values indicate higher perceived likelihood. In terms of the "alcohol myopia" theory, suggesting the need to get home (MacDonald et al. 1995, 97) or to go to work provides strong "cues" that may prompt an ill-considered response among students in the situation.

To measure the students' inclination to act imprudently, the impulsivity and risk seeking scales of Grasmick and co-authors (1993, p. 14) were used. Lower values indicate students think they are more likely to act in these ways.

A legitimacy of law scale was developed; it covered the aspects of its general binding character, the general expectation and reciprocal obligation to follow law, perceived benefit for society, as well as belief in good reasons and careful consideration behind law. Lower values indicate students are more in agreement with the statements related to legitimacy.

As the inclination to drive under the influence may depend on perceived objective risk, respondents were asked about the condition of roads and of vehicles, carelessness of other drivers, and the need to be alert at all times. Roads in the area of study have been evaluated as "medium high" or "medium risk", taking into account the number of deaths and serious injuries as well as the traffic density (Road Safety Foundation 2014, p. 16). Another type of risk to offending drivers is presented by the police, and the students estimated the likelihood of drivers generally and of themselves specifically being stopped. Again, lower values indicate higher risks of this kind.

Out of the 337 participants who completed the questionnaire, $68.2 \%$ stated being female (coded " 1 ") and $30.3 \%$ male (coded " 2 "). Due to the sample recruited from undergraduate students, $89.3 \%$ were aged between 18 and 25 , and $6.8 \%$ between 26 and 35 . Falling out of this age bracket were $2.9 \%$, while $0.9 \%$ of participants did not respond. Lower values indicate lower age. $23.7 \%$ had a responsibility to care for someone (coded " 1 " and not caring for someone " 2 "), for example parents or children ( $2.7 \%$ did not respond to this item). Participants were asked about their country of origin and $18.7 \%$ identified as "UK" nationals (including four Scottish students), 
$26.4 \%$ as "English" and $24.9 \%$ as "Welsh". ${ }^{4} 16.8 \%$ came from other countries in the world, with Chinese being most represented (13.9\%). Countries were dummy-coded, with " 1 " for belonging to one country, "0" for not belonging to it. $13.4 \%$ chose not to answer the nationality question. This may well indicate fear among some about being identified, possibly affecting disproportionally students from countries less numerously in those university lectures.

When asked about whether they possessed a driving license, 66.2\% reported 'Yes' (coded "1") and 32.6\% reported "No" (coded "2"). We did not exclude students without a driving license as their views may still matter, for example when their driver is under the influence of a substance, when friends debate such a situation, or when they will acquire a driving license. However, in our final (multivariate) analysis, we will control for having a driving license. The remaining $1.2 \%$ did not specify; this may be a result of the individual holding a learner permit. Only $14.8 \%$ (33) of those with a driving licence said they "never" drive. Of those 110 students who stated they did not have a driving licence, still $8.1 \%$ (9) indicated driving at least once a month. To distinguish whether there was a difference in driving styles depending on location, participants were to characterize the area where they dwelled; $53.7 \%$ indicated living in a rural (coded "1") and $44.2 \%$ in an urban area (coded " 2 ").

Four out of ten students said they "never" drive while a third used their cars "about five times per week" (Table 1). Almost half of the respondents indicated drinking at least once a week or more (Table 1 ) and $16.9 \%$ about three times a week and more. Both variables, driving and drinking, were correlated on a bivariate level (Spearman Rho $=.16, \mathrm{n}=326, \mathrm{p}=.05)$. Lower values indicate driving or drinking more frequently.

\section{TABLE 1}

\begin{tabular}{|c|c|c|c|c|c|c|c|c|}
\hline & 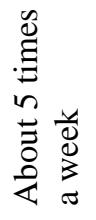 & 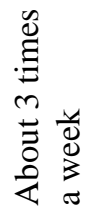 & 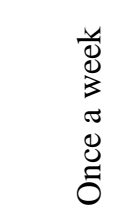 & 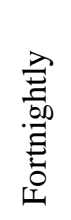 & 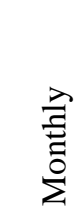 & خ̀ & 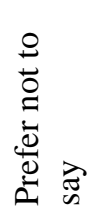 & $=$ \\
\hline $\begin{array}{l}\text { 1. How often do } \\
\text { you drive? } \\
2 \text {. How often do } \\
\text { you consume } \\
\text { alcohol? }\end{array}$ & 32.6 & 10.1 & 4.5 & 0.6 & 11.6 & 39.5 & 1.5 & 333 \\
\hline
\end{tabular}

\section{Table 1. Frequency of driving and of drinking alcohol.}

(Percentages: differences to 100 are missing answers).

When participants were asked whether they take legal medication that may affect their driving, 2.7\% answered "Yes, routinely", 5.0\% "Yes, occasionally", and 88,7\% "No". (2.1\% preferred not to say, data for $1.5 \%$ were missing.) Lower values indicate taking such medication more frequently. There was no bivariate correlation with how often the participants drove (Spearman Rho $=.05, \mathrm{n}=325$, n.s.).

\section{Results}

Students were more likely to drive under medication coming with a warning than under the influence of alcohol $(t=11.152, \mathrm{df}=327, \mathrm{p}=.001)$. The overwhelming majority stated they would not drive under the influence of alcohol, 80.1 and $73.3 \%$ (Table 2). Only $6.6 \%$ (21) would drive home and $10.4 \%$ (35) to work (combining answers "very likely", "likely" and "somewhat likely"). 13.1\% said they would "not

\footnotetext{
${ }^{4}$ In the UK, many people self-identify as "English", "Welsh" or "Scottish", reflecting in part major political developments towards either devolution of powers to those constituent parts of the UK or full national independence. The questionnaire therefore offered three more alternatives in addition to "UK" for domestic students to indicate their nationality.
} 
very likely" drive home and $15.7 \%$ "not very likely" to work. The picture changes when it comes to the medication item; $28.5 \%$ (96 out of 337) would be inclined to drive home and $29.4 \%$ (99) would drive to work. For about a quarter, driving under medication is "not very likely" and only for around $45 \%$ "not likely at all". Driving home and to work under medication are more interrelated than the corresponding alcohol items (Table 2). Slightly more students are inclined to drive under the influence of alcohol to get to work than to drive home $(t=3.070, \mathrm{df}=333, \mathrm{p}=$ .002 ).

\section{TABLE 2}

\begin{tabular}{|c|c|c|c|c|c|c|c|c|c|}
\hline & \multicolumn{6}{|c|}{ Percentages } & \multicolumn{3}{|c|}{ Correlations } \\
\hline & $\begin{array}{l}\text { Very } \\
\text { likely }\end{array}$ & Likely & $\begin{array}{l}\text { Some- } \\
\text { what } \\
\text { likely }\end{array}$ & $\begin{array}{r}\text { Not } \\
\text { very } \\
\text { likely }\end{array}$ & $\begin{array}{r}\text { Not at } \\
\text { all } \\
\text { likely }\end{array}$ & $\begin{array}{l}\text { Don't } \\
\text { know }\end{array}$ & 1. & 2. & 3. \\
\hline $\begin{array}{l}\text { 1. Alcohol, } \\
\text { driving home }\end{array}$ & 0.6 & 2.4 & 3.3 & 13.1 & 80.1 & 0.6 & & & \\
\hline $\begin{array}{l}\text { 2. Alcohol, } \\
\text { driving to } \\
\text { work }\end{array}$ & 0.6 & 3.3 & 6.5 & 15.7 & 73.3 & 0.6 & .49 & & \\
\hline $\begin{array}{l}\text { 3. Medication, } \\
\text { driving home }\end{array}$ & 4.5 & 6.2 & 17.8 & 24.9 & 44.8 & 1.8 & .32 & .34 & \\
\hline $\begin{array}{l}\text { 4. Medication, } \\
\text { driving to } \\
\text { work }\end{array}$ & 3.6 & 8.6 & 17.2 & 22.0 & 47.2 & 1.5 & .31 & .40 & .81 \\
\hline $\begin{array}{l}\text { Suspicious } \\
\text { drivers stopped }\end{array}$ & 6.2 & 23.4 & 46.0 & 18.7 & 2.1 & 3.3 & & & \\
\hline $\begin{array}{l}\text { Respondent } \\
\text { stopped in } \\
\text { control on road }\end{array}$ & 6.8 & 11.6 & 25.8 & 35.0 & 11.9 & 8.6 & & .17 & \\
\hline
\end{tabular}
Table 2. I nclination to drive under the influence of alcohol and medication and perceived likelihood of being stopped by police.
(Percentages: differences to $\mathbf{1 0 0}$ are missing answers. Correlations are Spearman Rho, $301 \leq \mathrm{n} \leq 335, \mathrm{p}=.01$ ).

While the respondents assumed suspicious drivers are somewhat likely to be stopped by the police, they themselves (Table 2 ) rather believed they were less likely to be affected by a police control on the road $(t=-7.190, \mathrm{df}=300, \mathrm{p}=.001)$.

A legitimacy scale (Table 3 ) was constructed from seven items measuring different aspects (Cronbach's alpha $=.838$ ). Generally, most students wanted to follow the law; it is believed laws are made for good reason. A further $56.4 \%$ stated that they make a strong effort not to break legal rules. By far most had the underlying feeling of reciprocal obligation and that it is better if everyone follows the law. However, students had slight reservations when it came to the item "all aspects are considered and all opinions heard when a law is drafted". 
TABLE 3

\begin{tabular}{|c|c|c|c|c|c|}
\hline & $\begin{array}{r}1= \\
\text { Very }\end{array}$ & 2 & 3 & 4 & $\begin{array}{r}5=\text { Not at } \\
\text { all }\end{array}$ \\
\hline 1. One always has to follow the law & 37.7 & 42.7 & 15.1 & 3.6 & 0.3 \\
\hline $\begin{array}{l}\text { 2. It is better for society if everyone sticks } \\
\text { to the law }\end{array}$ & 49.9 & 35.9 & 11.0 & 1.8 & 1.2 \\
\hline 3. I try not to break legal rules & 56.4 & 32.6 & 6.2 & 2.7 & 1.8 \\
\hline 4. Laws are usually made for good reason & 47.2 & 32.6 & 16.3 & 2.7 & 1.2 \\
\hline $\begin{array}{l}\text { 5. I trust that all aspects are considered and } \\
\text { all opinions heard when a law is drafted }\end{array}$ & 19.3 & 32.0 & 30.9 & 12.8 & 4.2 \\
\hline $\begin{array}{l}\text { 6. I expect others to observe the law and so } \\
\text { I myself need to observe the law }\end{array}$ & 44.2 & 36.8 & 14.5 & 3.0 & 1.2 \\
\hline $\begin{array}{l}\text { 7. In most cases it makes more sense to } \\
\text { follow the law as this is what other people } \\
\text { expect }\end{array}$ & 40.7 & 43.0 & 11.9 & 3.6 & 0.6 \\
\hline
\end{tabular}

Table 3. Legitimacy of the law, percentages.

( $335 \leq \mathrm{n} \leq 337$. Percentages: differences to 100 are missing answers).

Seven ratings aimed at determining how the participants perceived the dangerousness of driving (see Table 4). The students gravitated towards assuming rather hazardous circumstances. For example, a full $76.9 \%$ were aware of the need for drivers to be "alert all the time". Eight out of ten respondents agreed, "People on the roads do not always take care". Of the seven items, one, the condition the roads are in, proved to measure a different dimension than dangerousness of the roads. A series of exploratory factor analyses arrived at also leaving out the fifth item in Table 4 and suggested two factors (see Table 5) are driving perceived dangerousness of the roads:

- Three items measured dangers emanating from the driver: need to be alert all the time, tiredness and distraction. An index variable "driver failure" was formed of the three (Cronbach's alpha $=.667$ ).

- Two items related to dangerous roads and unsafe vehicles. They are significantly related (Pearson's $r=.305, p \leq .001$ ) and were combined to represent this type of dangers.

TABLE 4

\begin{tabular}{|c|c|c|c|c|c|}
\hline & $\begin{array}{r}1= \\
\text { Very }\end{array}$ & 2 & 3 & 4 & 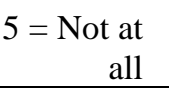 \\
\hline 1. The roads have become dangerous & 13.9 & 33.8 & 31.2 & 15.7 & 5.0 \\
\hline 2. Drivers need to be alert all the time & 76.9 & 16.0 & 5.0 & 1.5 & .06 \\
\hline $\begin{array}{l}\text { 3. Drivers who are tired cause more } \\
\text { accidents }\end{array}$ & 48.4 & 33.2 & 14.2 & 2.7 & 1.2 \\
\hline 4. Distraction causes a lot of accidents & 54.6 & 35.6 & 7.4 & 1.5 & 0.6 \\
\hline $\begin{array}{l}\text { 5. People on the roads do not always } \\
\text { take care }\end{array}$ & 41.8 & 33.8 & 15.4 & 6.5 & 2.4 \\
\hline 6. Roads are - not - in good condition & 5.3 & 18.1 & 49.0 & 22.0 & 5.6 \\
\hline $\begin{array}{l}\text { 7. There are a lot of unsafe vehicles on } \\
\text { the roads }\end{array}$ & 14.2 & 28.5 & 37.4 & 18.1 & 1.8 \\
\hline
\end{tabular}

Table 4. Perceived dangerousness of driving, percentages.

( $N=336,337$. Percentages: differences to 100 are missing answers.

\# Original wording inversely "Roads are in good condition"). 
TABLE 5

\begin{tabular}{lrr} 
& \multicolumn{2}{r}{ Component } \\
\hline The roads have become dangerous & 1 & 2 \\
Drivers need to be alert all the time & .047 & .760 \\
Drivers who are tired cause more accidents & 680 & -.129 \\
Distraction causes a lot of accidents & .817 & .087 \\
There are a lot of unsafe vehicles on the roads & .791 & .138 \\
\end{tabular}

Table 5. Factor analysis for perceived dangerousness.

(Entries are factor loadings. Extraction Method: Principal Component Analysis. Rotation Method: Oblimin with Kaiser Normalization).

The respondents' inclination to engage in imprudent and risky behaviour is reported in Table 6. For most items, the majority of the students rather tended to disagree with the statements indicating unwise behaviour. Though, on items "acting on the spur of the moment", "pleasure here and now" and "doing something a little risky", there is almost an even split of affirmative answers and rejections. And for the remaining items, a sizeable minority did not go for the risk-aversive options. An exploratory factor analysis (Table 7 ) showed that there are two separable dimensions.

- The last four items in Table 7, "doing something a little risky", "take a risk just for the fun", "exciting to do things for which I might get in trouble" and "excitement and adventure are more important", are loading highly on a first factor describing risk-taking and excitement seeking behaviour. The four variables were therefore combined to one index variable (Cronbach's alpha $=$ .828), referred to as "risk seeking".

- Three items, "[not much] preparing for the future", "pleasure here and now" and "concern for the short run" are loading highly on a second factor. It suggests a "here and now" way of thinking without much regard for future consequences, which is aptly expressed in the term "impulsivity". Again, an index variable was formed (Cronbach's alpha $=.724$ ).

The first item in Table 7, "acting on the spur of the moment", cannot be clearly related to one of the two factors. 


\section{TABLE 6}

\begin{tabular}{|c|c|c|c|c|}
\hline & $\begin{array}{r}1= \\
\text { Strongly } \\
\text { agree }\end{array}$ & $\begin{array}{r}2= \\
\text { Agree } \\
\text { some- } \\
\text { what }\end{array}$ & $\begin{array}{r}3= \\
\text { Disagree } \\
\text { somewhat }\end{array}$ & $\begin{array}{r}4= \\
\text { Strongly } \\
\text { disagree }\end{array}$ \\
\hline $\begin{array}{l}\text { 1. I often act on the spur of the } \\
\text { moment without stopping to think }\end{array}$ & 7.1 & 40.9 & 41.8 & 9.2 \\
\hline $\begin{array}{l}\text { 2. I don't devote much thought and } \\
\text { effort to preparing for the future }\end{array}$ & 6.8 & 22.6 & 38.6 & 31.2 \\
\hline $\begin{array}{l}\text { 3. I often do whatever brings me } \\
\text { pleasure here and now, even at the } \\
\text { cost of some distant goal }\end{array}$ & 8.3 & 38.0 & 38.0 & 13.6 \\
\hline $\begin{array}{l}\text { 4. I'm more concerned with what } \\
\text { happens to me in the short run than in } \\
\text { the long run }\end{array}$ & 8.3 & 30.9 & 40.7 & 17.8 \\
\hline $\begin{array}{l}\text { 5. I like to test myself every now and } \\
\text { then by doing something a little risky }\end{array}$ & 8.3 & 41.2 & 33.8 & 15.1 \\
\hline $\begin{array}{l}\text { 6. Sometimes I will take a risk just for } \\
\text { the fun of it }\end{array}$ & 5.6 & 29.4 & 37.1 & 26.4 \\
\hline $\begin{array}{l}\text { 7. I sometimes find it exciting to do } \\
\text { things for which I might get in trouble }\end{array}$ & 5.0 & 22.3 & 36.5 & 35.0 \\
\hline $\begin{array}{l}\text { 8. Excitement and adventure are more } \\
\text { important to me than security }\end{array}$ & 4.7 & 24.9 & 39.8 & 29.7 \\
\hline
\end{tabular}

Table 6. I nclination towards imprudent behaviour, percentages.

( $330 \leq \mathrm{n} \leq 334$. Percentages: differences to 100 are missing answers).

TABLE 7

Component

\begin{tabular}{lrr}
\hline $\begin{array}{l}\text { I often act on the spur of the moment without stopping } \\
\text { to think }\end{array}$ & .363 \\
$\begin{array}{l}\text { I don't devote much thought and effort to preparing for the future } \\
\text { I often do whatever brings me pleasure here and now, even at the cost of some }\end{array}$ & -.109 .860 \\
distant goal & .209 & .674 \\
I'm more concerned with what happens to me in the & -.028 & .809 \\
short run than in the long run & .746 & .046 \\
I like to test myself every now and then by doing something a little risky & .912 & -.065 \\
Sometimes I will take a risk just for the fun of it & .791 & .029 \\
I sometimes find it exciting to do things for which I might get in trouble & .774 & -.029 \\
Excitement and adventure are more important to me than security &
\end{tabular}

Table 7. Factor analysis for imprudent behaviour.

(Entries are factor loadings. Extraction Method: Principal Component

Analysis. Rotation Method: Oblimin with Kaiser Normalization).

\subsection{Multivariate Analysis}

Stepwise regression analyses were conducted to test the factors affecting driving under the influence of alcohol to work or home, and of medication, again to work or home (Table 8). While the independent variables all taken together explain just about $7 \%$ of the inclination to drive under the influence of alcohol, they account for $23 \%$ of the inclination to drive under medication where advised not to. 
TABLE 8

\begin{tabular}{|c|c|c|c|c|c|c|c|c|c|c|c|}
\hline & \multicolumn{5}{|c|}{ Driving under alcohol } & \multicolumn{6}{|c|}{ Driving under medication } \\
\hline & $\begin{array}{r}\text { Socio-demo- } \\
\text { graphics }\end{array}$ & \multicolumn{2}{|c|}{$\begin{array}{r}\text { Additional } \\
\text { factors }\end{array}$} & \multicolumn{2}{|c|}{$\begin{array}{r}\text { Attitudes } \\
\text { and per- } \\
\text { ceptions }\end{array}$} & \multicolumn{2}{|c|}{$\begin{array}{r}\text { Socio- } \\
\text { demo- } \\
\text { graphics }\end{array}$} & \multicolumn{2}{|c|}{$\begin{array}{r}\text { Additional } \\
\text { factors }\end{array}$} & \multicolumn{2}{|c|}{$\begin{array}{l}\text { Attitudes and } \\
\text { perceptions }\end{array}$} \\
\hline & Beta Sig. & Beta & Sig. & Beta & Sig. & Beta & Sig. & Beta & Sig. & Beta & Sig. \\
\hline Age & -.002 .969 & .041 & .509 & .074 & .296 & -.092 & .105 & -.022 & .696 & -.049 & .449 \\
\hline Gender & -.087 .126 & -.066 & .257 & -.016 & .817 & -.048 & .393 & -.033 & .541 & .045 & .489 \\
\hline $\begin{array}{l}\text { Urban area } \\
\text { living }\end{array}$ & -.048 .425 & -.043 & .486 & -.034 & .615 & .005 & .937 & -.027 & .636 & -.014 & .823 \\
\hline $\begin{array}{l}\text { UK and } \\
\text { Scotland }\end{array}$ & .107 .183 & .140 & .105 & .182 & .050 & .127 & .111 & .073 & .365 & .110 & .194 \\
\hline Wales & .068 .437 & .149 & .111 & .101 & .323 & .072 & .403 & .085 & .326 & .047 & .613 \\
\hline England & .114 .183 & .153 & .098 & .173 & .081 & .122 & .147 & .078 & .367 & .090 & .321 \\
\hline China & .129 .088 & .101 & .200 & .133 & .147 & .305 & .001 & .219 & .003 & .217 & .010 \\
\hline Other countries & .033 .583 & .038 & .538 & .052 & .449 & .052 & .381 & .039 & .497 & .043 & .492 \\
\hline $\begin{array}{l}\text { Caring } \\
\text { reponsibility }\end{array}$ & & .065 & .327 & .065 & .396 & & & .142 & .024 & .141 & .047 \\
\hline $\begin{array}{l}\text { Frequency } \\
\text { alcohol } \\
\text { consumption }\end{array}$ & & .125 & .051 & .070 & .323 & & & .170 & .005 & .127 & .052 \\
\hline $\begin{array}{l}\text { Taking } \\
\text { medication }\end{array}$ & & .118 & .040 & .114 & .074 & & & .155 & .004 & .122 & .038 \\
\hline $\begin{array}{l}\text { Has driving } \\
\text { licence }\end{array}$ & & .010 & .900 & -.009 & .912 & & & .183 & .015 & .184 & .019 \\
\hline $\begin{array}{l}\text { Frequency } \\
\text { driving }\end{array}$ & & .186 & .028 & .170 & .069 & & & .143 & .071 & .095 & .261 \\
\hline $\begin{array}{l}\text { Legitimacy of } \\
\text { law }\end{array}$ & & & & -.049 & .502 & & & & & -.168 & .012 \\
\hline Driver failure & & & & $\underline{-.120}$ & .089 & & & & & -.007 & .916 \\
\hline $\begin{array}{l}\text { Unsafe roads } \\
\text { and vehicles }\end{array}$ & & & & -.114 & .102 & & & & & -.029 & .653 \\
\hline Risk seeking & & & & .106 & .205 & & & & & .139 & .072 \\
\hline Impulsivity & & & & -.032 & .658 & & & & & .061 & .357 \\
\hline Drivers stopped & & & & .043 & .506 & & & & & -.043 & .475 \\
\hline $\begin{array}{l}\text { Themselves } \\
\text { stopped }\end{array}$ & & & & -.055 & .434 & & & & & -.073 & .255 \\
\hline $\mathrm{N}$ & 323 & 304 & & 256 & & 319 & & 300 & & 254 & \\
\hline Significance & .522 & .001 & & .010 & & .001 & & .001 & & .001 & \\
\hline Adjusted $\mathrm{R}^{2}$ & -.003 & .050 & & .070 & & .078 & & .228 & & .234 & \\
\hline
\end{tabular}

Table 8. Stepwise regressions for driving under the influence.

(Dependant variables: lower values signify higher likelihood to drive.

Betas significant at $\mathbf{p}=.05$ in bold characters, marginally significant $\mathbf{p} .=$ .10 underlined).

In both cases, socio-demographic variables alone explain little or nothing, and the level of explanation improves only when the additional factors of consuming alcohol, taking medication coming with a warning not to drive, possessing a driving licence, frequency of driving and having a role as carer for others are entered. These factors are connected with driving under the influence on a more practical level. The explained variance rises slightly from $\mathrm{R}^{2} .050$ to .070 for driving under alcohol and 
very little from $\mathrm{R}^{2} .228$ to .234 to driving under medication when the attitude and perception of risk variables come into play. It is these full models, which will be described in the following.

Table 8 shows some significant influences on the dependent variables. The perceived legitimacy of the law was unrelated to driving under alcohol but those who rated the law's authority higher were less likely to drive under the effect of medication. Observing the drivers or the roads and vehicles as dangerous did not influence driving under medication, and only perceived dangers emanating from drivers marginally significantly reduced the readiness for drink driving $(p=.089)$. The inclination to engage in imprudent behaviour measured via its risk seeking and impulsivity elements, did not affect driving under alcohol, while driving under medication was marginally more accepted as an option by students who were generally more prone to risky behaviour $(p=.072)$.

Furthermore, respondents taking medication that affects driving, was positively related to driving under the influence of medication and they were marginally more likely to drive under the influence of alcohol $(p=.074)$. When it comes to holding a driving license and the frequency of driving, results differ. Students holding a driving licence stated less often they would drive under medication, but having a licence had no effect on drink driving. Students driving more frequently were marginally more likely to operate a motor vehicle under the influence of alcohol $(p=0.69)$, but driving frequency was unrelated to controlling a car under medication that comes with a warning. Those who drank alcohol more frequently were more likely to drive under medication, only just failing the significance level $(p=.052)$, but this factor was not significantly related to driving under the influence of alcohol.

When it comes to national origin, students indicating coming from the UK (and Scotland) were less likely to drive under alcohol (students "from England" marginally significantly, $p=.081$ ). Respondents professing a "Welsh" nationality showed no significant patterns, as did students from the "other countries" category. Chinese students were significantly less likely to drive under medication.

Respondents who had responsibilities to care for others were significantly more likely to drive under medication, but not alcohol.

Several other factors were unrelated to willingness to drive under the influence. The perceived likelihood of the police stopping drivers was not related, for both measures used. The demographic factors of age and gender had no significance. The same applied to living in an urban or rural environment.

\section{Discussion}

The present study enquires into the antecedents of student's attitude to driving under the influence of alcohol or of prescribed medication where advised not to control a car. Previous literature did not address the connection between the two dangerous behaviours and the legitimacy of law. Partially different conclusions were arrived at for both types of dangerous behaviour.

More students assumed they were ready to drive under such medication than under the influence of alcohol. A study with English drivers, including young drivers, similarly showed that they "were generally unwilling to drink and drive and had a negative attitude towards drink-driving" (Rivis et al. 2011, pp. 449-450). In our study, students identifying as from England were marginally less likely to drink drive and the group of those identifying as from the UK (or from Scotland) were significantly less likely not to drink drive.

The inclination to drive under alcohol and medication coming with a warning proved most influenced by some factors of a more practical nature. They were: any duties to care for others, actually taking such medication, the frequency of drinking, the 
frequency of driving and possessing a driving licence. Though, not all of these factors influenced drink driving and driving under medication equally.

For people having responsibility to care for others, adverse consequences of driving under the influence may amount to a higher risk. In the present study carers were less anxious to drive under medication coming with a warning, but caring duties did not influence the inclination to drive under the influence of alcohol. The effect may have been different for older populations where caring for children or older relatives is more prevalent than for students. It is well possible that for carers the pressures to be home quickly and be at work in time takes precedence over safety concerns.

Respondents who indicated that they are taking a medication that affects their driving were more inclined to drive under the influence of such a medication and of alcohol, although the latter was only marginally significant. It suggests that even if their doctors may have advised them when prescribing the medication or if they have read the user information there was little effect.

The frequency of drinking was not significantly related to inclination to drive under alcohol. Indeed, "binge drinking" on few occasions is more typical for the alcohol consumption patterns of students. Our study may suggest that occasional and frequent drinkers share the same attitude to drink driving. However, drinking more often was marginally significantly related to driving under medication. Taking medication and at the same time, consuming alcohol worsens negative effects on the ability to drive safely (Berghaus et al. 2006, p. A2106), so the survey results give rise to concern.

Students possessing a driving license were more likely to drive under medication where they should not. Frequent drivers were more prepared to control a motor vehicle under the influence of alcohol (although, this is another marginally significant result). They may be more confident in their skills and therefore disregard the dangers of drinking - but in our sample, not of medication. Those respondents may have been in more situations in which they were tempted to drive under the influence of alcohol; if they got away then, they may think nothing happens in the future. This interpretation chimes with Ajzen's Theory of Planned Behaviour, stating that beliefs about the consequences influence attitudes towards a specific behaviour.

Age and gender were found unrelated to driving under the influence of medicines impacting on the ability to control a car, and under alcohol as well in our sample, most likely because our respondents were students. Years of higher education might have suppressed the impact of age and gender found in studies on risky behaviour, and most students were of a similar age anyhow. No difference also appeared for respondents living in an urban or rural environment, although the latter are presumably more dependent on cars.

We could not find any effect of the perceived likelihood of controls on the road which would be one of the hazards when driving under the influence. Indeed, because of budget cuts, police presence in the UK is spread more thinly. ${ }^{5}$ On top of this, the perceived certainty of sanctions does not always reduce deviant behaviour (Paternoster et al. 1983, pp. 472-475).

The impact of attitudinal factors like the tolerance or indeed appetite for risk, the legitimacy of law and the perceived dangerousness of driving proved small in comparison to other significant factors, mentioned before of more immediate practical relation to driving under alcohol and prescription drugs.

Previous studies demonstrated that imprudent and risky general behaviour patterns facilitate offending behaviour. The present research distinguishes between two different dimensions: "impulsivity", an occupation with the "here and now" to the

5 The local North Wales Police also has in recent years relaxed its formerly strict road controls, for background: Dalton et al. 2009. 
detriment of future planning, and "risk seeking", being prepared to take risks, if not seeking risk. The results only showed a marginally significant relation of risk seeking with driving under the influence of medication (not alcohol in this study). Those more inclined to take risks in many situations, are therefore less conscientious about driving while using medication.

While the perceived legitimacy of law was found to be related to driving under medication, this was not the case for drink driving. Individuals who deemed the law legitimate were more likely to reject driving under a medication that influences the ability to drive a car. A different strand of research, discussed below, draws on the influence of peers on the internalized norms of drivers. The views of peers and the demands of the law will not always coincide. For now, we note that the belief in the legitimacy of law, which was rather strong among the student respondents, had a relation to the preparedness to drive under medication.

Chinese respondents did not differ from other students in our sample regarding their inclination to drive under alcohol, where the majority of all students clearly said they would not, anyhow. But Chinese nationals showed a stronger resistance against driving under medication coming with a warning. Future studies may also draw on the finding in Hassan and team's (2016, p. 83) meta-study of the Theory of Planned Behaviour, that there is a higher correlation between "subjective norm" and intention to act in countries which fall under Geert Hofstede's (1993, 1997, p. 32) category of "high power distance orientation". China forms one of those countries with stricter allegiance to authorities, rules and laws.

The perceived dangerousness of driving, appeared to have two different dimensions in our final analysis: dangers emanating from drivers and dangers external to drivers, such as dangerous roads and unsafe vehicles. Both dimensions of dangerousness did not relate to driving under medication, but respondents being more aware of driverrelated dangers were marginally less inclined to drink drive. The very public discourse around the dangers of drink driving may have established a pattern with alcohol use and consequent inability to cope with risks on the road. A similar discussion is lacking for driving under medication; people may then resort to basic practical considerations, or perhaps even broader inclinations to follow the law or not.

\subsection{Limitations}

There are limitations of the present study, and probably more so when it comes to alcohol than to medication. Participating students were not drunk and in the actual situation in which they are tempted to drive. It is when students are intoxicated and in the presence of a relevant cue that they are more likely to say they will drink drive (MacDonald et al. 1995, p. 982). Then the "alcohol myopia" sets in. Nevertheless, a large enough part of the present sample indicated they would perhaps drive under the influence of alcohol to allow analysing the associated factors. In a real setting when intoxicated, more of the respondents may look favourably at drink driving. The exact same argument cannot be made for driving under medication, because in general, prescribed drugs will be taken for a longer time period and typically not in a short episodic fashion like the characteristic binge drinking by students. Some respondents may therefore even have been under the influence of their prescription while responding to the survey in the classroom. Others may have taken their medicine so that the effect attenuates at daytime, allowing them to safely commute to the university. Nevertheless, even for them, the issues presented had a more immediate practical meaning.

In addition, the present study has not only relevance in relation to the actual drivers, but also for passengers. The results may suggest which factors are at play when passengers will not agree to enter into an incapacitated driver's car, or when people act to prevent someone from driving under the influence. Further research on these constellations may take the factors identified in this study into account. 
With self-completion questionnaires and anonymity being assured, there is still the possibility that participants provide a socially desirable answer. Again, the chance of students to drink drive may in reality be somewhat higher than suggested by the respondents. It is quite plausible that the same holds true for driving under medication, even if more students declared to be prepared for it anyhow. But, this does not necessarily mean that the factors impacting on such behaviours identified in the present study do not influence their intentions.

Another aspect distinguishes the two behaviours discussed here. Medication is usually taken individually, and the actual presence of others has no bearing on it. Drinkers, however, may be enticed by friends, or other people e.g. in a pub. Both, individuals under the influence of medication and alcohol, may sometimes feel obliged to drive others home or to work. The present study does not take into account the factor of peer pressure, or more broadly: peer influence. Younger people may be especially susceptible to it (Gardner and Steinberg 2005, pp. 629-632, Fernandes et al. 2010, p. 191). In relation to drink driving, Chan and co-authors (2010, pp. 1552-1553) reported that when Chinese respondents thought that their friends or family approved of drink driving, it indirectly affected their intention to do so via personal attitudes and the belief that they are able to drive while being drunk. However, in at least one study, peer influence on adolescents' abuse of prescription drugs was found to be weaker than peer influence on the consumption of illegal drugs, pointing at different circumstances under which the former takes place (Schroeder and Ford 2012, p. 18). It is important to note that when it comes to potentially dangerous activity, peer pressure can have negative as well as positive, imprudence inhibiting, effects (Plant and Plant 1997, pp. 200-201, 203, Elias et al. 2017, p. 189). For example, Rivis and her team (2011, p. 449) found that, English male drivers "perceived strong pressure from significant others to not drink and drive". In terms of the Theory of Planned Behaviour, peer influence impacts on "subjective norm". The present study focused on the perceived legitimacy of law, which is a more complex concept, after all the law may contradict individual and group norms, and "subjective norm" does not capture the conflict arising. Our study did not control for peer pressure and future research may include this on top of the factors in the study reported here.

University students are not only younger than the average population but also more educated. It is entirely possible that non-students in the same age group-and more generally non-university educated people-give different answers to the questions investigated here. Older, less educated and less affluent drivers appeared as highrisk when it comes to drink driving and causing accidents in the UK (Owen et al. 2019, pp. 457-458). Our study also had a larger percentage of female than male respondents, and it may be that aspects specific to males emerge in a larger sample of males. Researchers may want to widen the demographic focus and for people who are not students, they may find a stronger effect of factors such as caring responsibilities or find that having to go to work is more of a pressure.

The results of this study regarding drink driving may not apply fully in countries in which females getting drunk is not accepted by society. There will then be more pressures to prevent this. The same cannot be said for driving under prescription drugs as societies will hardly discriminate between genders in relation to medication.

A factor not considered in the present study was the individuals' belief in their effectiveness at avoiding accidents while drink driving (Elias et al. 2017), or when taking a medication that comes with a warning. They may think "that they are still safe drivers" (Beck 1981, p. 386). This idea can be nurtured by the experience to have arrived safely regardless of having had too much alcohol, or when driving under medication.

For their subgroup of Norwegians aged below the age of 35 only, Moan and Rise (2011) identified the belief to have control over the behaviour, to be easily able to avoid the situation, to be the one decisive factor in the intention to drive under alcohol. For French students, Potard and co-authors (2018, pp. 42-43) also arrived 
at the conclusion that perceived behavioural control, together with past experience, had an impact on drink driving. The belief of being in control, one of the factors highlighted by the Theory of Planned Behaviour, is another aspect that could be covered in subsequent research.

Finally, our study centred on people's intentions to drive under alcohol influence or when taking medication that impairs one's ability to control a car if in a tempting situation. However, the road from intentions to actions is still long. A panel study design would be able to trace if attitudes and intentions led to actual behaviour later.

\section{Conclusion}

While there is ample research demonstrating the issues around drink driving, to the best of our knowledge our study may be the first to compare driving under the influence of alcohol with driving under medication that affects the ability to control a car. The inclination to drive under medication was higher than to drive under alcohol among the respondents. Research could establish if this pattern applies to the UK population more generally, and even internationally.

We found the inclination to drive under alcohol related to taking medication that impacts on driving, to the frequency of driving and to not thinking that drivers on the road form a hazard. Although, these factors were marginally significant, the result gives rise for concern. Students identifying as from England and "from the UK" (including Scotland), were less likely to drive intoxicated by alcohol. This may indicate an effect of awareness campaigns.

Driving under medication that impacts on the ability to control a vehicle, was seen as a less likely choice by students who generally saw law as legitimate, and by students from China. It demonstrates the impact of socialization processes. We found some support for the assumption that a more risk seeking general attitude favours the inclination to drive under medication, as well as aspects directly related to the activity of driving and students' lives such as consuming alcohol more frequently, taking such a medication, and possessing a driving license. Even caring for someone increased the likelihood. While there are campaigns against drink driving for decades and the reluctance of the student sample to commit the offence may be a product of it; there is a lack of awareness and campaigns for driving under prescription drugs impeding the ability to control a car. In this situation, the more practical aspects mentioned above come to the fore and even more general attitudes, such as the belief in the binding qualities of law and the personal appetite for risky behaviour.

Measures to prevent driving under the influence of medication should match the intensity of those directed against alcohol. They have to include at least public campaigns to raise awareness of the dangers (DuPont 2010, pp. 130-131). Advertisements informing of dangers related to alcohol reached young drinkers in the UK (e.g. Engineer et al. 2003, p. 67). Ways could be found to confront the public with the effect medication can have on driving, for example shattering confidence by demonstrating the reduced capacity to react to situations on the road. A method to influence risky behaviour would be to strengthen the impression that peers disregard it and to cultivate a negative image of driving under the influence (Rivis et al. 2011, p. 454 in relation to drink driving). For students, higher education institutions and student unions could run awareness campaigns about the dangerousness of driving under prescription drugs that affect the ability to control a car. Another way to address the problem is to prescribe alternative drugs (Moskowitz 2009, p. 120), or use other alternative therapies. Finally, doctors prescribing medication should be aware of patients' reliance on driving and where possible, decide for an alternative therapy where available, or find a way of administering the drug that is less likely to impact on driver's ability (Berghaus et al. 2006). Neither relying on individual rationality nor on the binding character of the law will be enough. 


\section{References}

Ajzen, I., 1991. The theory of planned behaviour. Organizational Behavior and Human Decision Processes [online], 50(2), 179-211. Available from: https://doi.org/10.1016/0749-5978(91)90020-T [Accessed 12 September 2019].

Ajzen, I., 2002. Residual effects of past on later behavior: Habituation and reasoned action perspectives. Personality and Social Psychology Review [online], 6(2), 107-122. Available from: https://doi.org/10.1207/S15327957PSPR0602_02 [Accessed 12 September 2019].

Beck, K.H., 1981. Driving while under the influence of alcohol: Relationship to attitudes and beliefs in a college population. American Journal of Drug and Alcohol Abuse [online], 8(3), 377-88. Available from: https://doi.org/10.3109/00952998109009561 [Accessed 12 September 2019].

Berghaus, G., Käferstein, H., and Rothschild, M.A., 2006. Arzneimittel und Fahrsicherheit. Deutsches Ärzteblatt, 103(31-32), A2104-2109.

Botchkovar, E.V., and Broidy, L., 2012. Parenting, self-control, and the gender gap in heavy drinking: The case of Russia. International J ournal of Offender Therapy and Comparative Criminology [online], 57(3), 357-376. Available from: https://doi.org/10.1177/0306624X11435318 [Accessed 12 September 2019].

Brennan, A.F., Walfish, S., and AuBuchon, P., 1986. Alcohol use and abuse in college students: I. A review of individual and personality correlates. International J ournal of the Addictions [online], 21(45), 449-474. Available from: https://doi.org/10.3109/10826088609083536 [Accessed 12 September 2019].

Byrnes, J.P., Miller, D.C., and Schafer, W.D., 1999. Gender differences in risk taking: A meta-analysis. Psychological Bulletin [online], 125(3), 367-383. Available from: http://doi.org/10.1037/0033-2909.125.3.367 [Accessed 12 September 2019].

Carpenter, C.S., 2005. Heavy alcohol use and the commission of nuisance crime: Evidence from underage drunk driving laws. The American Economic Review [online], 95(2), 267-272. Available from: https://doi.org/10.1257/000282805774670220 [Accessed 12 September 2019].

Castillo, J.M., Jivraj, S., and Ng Fat, L., 2017. The regional geography of alcohol consumption in England: Comparing drinking frequency and binge drinking. Health and Place [online], 43, 33-40. Available from: https://doi.org/10.1016/i. healthplace.2016.11.007 [Accessed 12 September 2019].

Chan, D.C.N., Wu, A.M.S., and Hung, E.P.W., 2010. Invulnerability and the intention to drink and drive: An application of the theory of planned behaviour. Accident Analysis and Prevention [online], 42(6), 1549-1555. Available from: https://psycnet.apa.org/doi/10.1016/j.aap.2010.03.011 [Accessed 12 September 2019].

Dalton, I., et al., 2009. Speeding, the Chief Constable and trust in North Wales Police. Papers from the British Criminology Conference, 9, 92-110.

Dawkins, M.P., 1997. Drug use and violent crime among adolescents. Adolescence, 32(126), 395-404. 
Department for Transport, 2015. Reported Road Casualties in Great Britain:

Estimates for Accidents Involving Illegal Alcohol Levels: 2013 (Final) and 2014 (Provisional) [online]. 6 August. Available from:

https://www.gov.uk/government/uploads/system/uploads/attachment_data/fil e/451402/rrcgb-drink-drive-2013-final.pdf [Accessed 6 August 2015].

Department for Transport, 2017. Table RAS51001: Estimated Number of Reported Drink Drive Accidents and Casualties in Great Britain: 1979-2015 [online].

Statistical data set. 2 February update. Available from:

https://assets. publishing. service.gov.uk/government/uploads/system/uploads lattachment_data/file/827490/ras51001.ods [Accessed 10 April 2017].

DuPont, R.L., 2010. Prescription drug abuse: An epidemic dilemma. J ournal of Psychoactive Drugs [online], 42(2),127-132. Available from: https://doi.org/10.1080/02791072.2010.10400685 [Accessed 12 September 2019].

Eicher, C.C., 2016. Und? Schon vergessen? ADAC Motorwelt, February, pp. 12-17.

Elias, W., et al., 2017. Factors influencing the decision to engage in alcoholimpaired driving among Arab-Israeli youths. Transportation Research Part F [online], 44(1), 180-191. Available from:

https://doi.org/10.1016/j.trf.2016.09.024 [Accessed 12 September 2019].

Engineer, R., et al., 2003. Drunk and Disorderly: A Qualitative Study of Binge Drinking Among 18- to 20-year-olds [online]. Home Office Research Study 262. London: Home Office Research, Development and Statistics Directorate. February. Available from: https://pdfs.semanticscholar.org/74ed/008d2b8c35cd482c75b76d732555148 93757.pdf [Accessed 12 September 2019].

Feest, J., 1968. Compliance with legal regulations: Observation of stop sign behaviour. Law and Society Review [online], 2(3), 447-461. Available from: https://doi.org/10.2307/3052898

Fernandes, R., Hatfield, J., and Job, R.F.S., 2010. A systematic investigation of the differential predictors for speeding, drink-driving, driving while fatigued, and not wearing a seat belt, among young drivers. Transportation Research Part F: Traffic Psychology and Behaviour [online], 13(3), 179-196. Available from: https://doi.org/10.1016/j.trf.2010.04.007 [Accessed 12 September 2019].

Frankfurter Allgemeine Zeitung, 2016. So viele "Nieraucher" wie noch nie. Frankfurter Allgemeine Zeitung, 7 April, p. 9.

Gardner, M., and Steinberg, L., 2005. Peer influence on risk taking, risk preference, and risky decision making in adolescence and adulthood: An experimental study. Developmental Psychology [online], 41(4), 625-635. Available from: https://doi.org/10.1037/0012-1649.41.4.625 [Accessed 12 September 2019].

George, S., Rogers, R.D., and Duka, T., 2005. The acute effect of alcohol on decision making in social drinkers. Psychopharmacology [online], 182(1), 160169. Available from: https://doi.org/10.1007/s00213-005-0057-9 [Accessed 12 September 2019].

Gonzálves, M.T., et al., 2015. Prevalence and predictors of driving under the influence in Spanish youngsters. Drugs and Alcohol Dependence [online], 146, p. e125. Available from: https://doi.org/10.1016/j.drugalcdep.2014.09.258 [Accessed 12 September 2019].

Gosselin, D., et al., 2010. Comparative optimism among drivers: An intergenerational portrait. Accident Analysis and Prevention [online], 42(2), 734-740. Available from: https://doi.org/10.1016/j.aap.2009.11.001 [Accessed 12 September 2019]. 
Government Digital Service, 2018a. Drink Driving Penalties [online]. Available from: https://www.gov.uk/drink-driving-penalties [Accessed 15 February 2018].

Government Digital Service, 2018b. Drugs and Driving: The Law [online]. Available from: https://www.gov.uk/drug-driving-law [Accessed 15 February 2018].

Government Digital Service, 2019. The Drink Drive Limit [online]. Available from: https://www.gov.uk/drink-drive-limit [Accessed 30 J une 2019].

Grasmick, H.G., et al., 1993. Testing the core empirical implications of Gottfredson and Hirschi's general theory of crime. Journal of Research in Crime and Delinquency [online], 30(1), 5-29. Available from: https://doi.org/10.1177\%2F0022427893030001002 [Accessed 13 September 2019].

Hamnett, H.J., and Poulsen, H., 2018. The effect of lowering the legal drink-drive limit on the toxicological findings in driver fatalities: A comparison of two jurisdictions. J ournal of Forensic Sciences [online], 63(5), 1457-1465. Available from: https://doi.org/10.1111/1556-4029.13747 [Accessed 12 September 2019].

Hassan, L.M., Shiu, E., and Parry, S., 2016. Addressing the cross-country applicability of the theory of planned behaviour (TPB): A structured review of multi-country TPB studies. J ournal of Consumer Behaviour [online], 15(1), 7286. Available from: https://doi.org/10.1002/cb.1536 [Accessed 12 September 2019].

Hatfield, J., and Fernandes, R., 2009. The role of risk-propensity in the risky driving of younger drivers. Accident Analysis and Prevention [online], 41(1), 25-35. Available from: https://doi.org/10.1016/j.aap.2008.08.023 [Accessed 12 September 2019].

Hofstede, G., 1993. Interkulturelle Zusammenarbeit [online]. Wiesbaden: Gabler. Available from: https://doi.org/10.1007/978-3-322-90037-1 [Accessed 12 September 2019].

Hofstede, G., 1997. Lokales Denken, globales Handeln. Munich: Deutscher Taschenbuch Verlag.

Lee, C.J., Geiger-Brown, J., and Beck, K.H., 2016. Intentions and willingness to drive while drowsy among university students: An application of an extended theory of planned behavior model. Accident Analysis and Prevention [online], 93, 113-123. Available from: https://doi.org/10.1016/j.aap.2016.05.002 [Accessed 12 September 2019].

Luhmann, N., 1975. Legitimation durch Verfahren. $2^{\text {nd }}$ ed. Darmstadt: Luchterhand.

MacDonald, T.K., Zanna, M.P., and Fong, G.T., 1995. Decision making in altered states: Effects of alcohol on attitudes toward drinking and driving. Journal of Personality and Social Psychology [online], 68(6), 973-985. Available from: https://doi.org/10.1037//0022-3514.68.6.973 [Accessed 12 September 2019].

Machura, S., 1997. The individual in the shadow of powerful institutions. Niklas Luhmann's "legitimation by procedure" as seen by critics. In: K.F. Röhl and S. Machura, eds., Procedural J ustice [online]. Aldershot: Ashgate, 181-205. Available from: https://doi.org/10.4324/9780429444524-9 [Accessed 12 September 2019].

Moan, I., and Rise, J., 2011. Predicting intentions to "drink and drive" using an extended version of the theory of planned behaviour. Accident Analysis and Prevention [online], 43(4), 1378-1389. Available from: https://doi.org/10.1016/j.aap.2011.02.012 [Accessed 12 September 2019]. 
Moskowitz, H., 2009. Driving under the influence. In: R. Ammermann, P.J. Ott and R.E. Tarter, eds., Prevention and Societal Impact of Drug and Alcohol Abuse. New York: Psychology Press, 109-123.

Owen, R., et al., 2019. Driving while impaired by alcohol: An analysis of drinkdrivers involved in UK collisions. Traffic Injury Prevention [online], 20(5), 453459. Available from: https://doi.org/10.1080/15389588.2019.1606909 [Accessed 12 September 2019].

Ozascilar, M., 2010. Substance abuse and its risks leading to a crime: An empirical research based on investigations in university students in Istanbul. US-China Law Review, 7(5), 57-63.

Paternoster, R., et al., 1983. Perceived risk and social control: Do sanctions really deter? Law and Society Review [online], 17(3), 457-479. Available from: https://doi.org/10.2307/3053589 [Accessed 12 September 2019].

Paton, G., 2019. Young drivers face night time ban. The Times, 18 J une, 1, 4.

Plant, M., and Plant, M., 1997. Alcohol education and harm minimisation. In: M. Plant, E. Single and T. Stockwell, eds. Alcohol: Minimising the Harm. What Works? London: Free Association Books, 193-210.

Potard, C., et al., 2018. Driving under the influence of alcohol and perceived invulnerability among young adults: An extension of the theory of planned behaviour. Transportation Research Part F: Traffic Psychology and Behaviour [online], 55(May), 38-48. Available from: https://doi.org/10.1016/i.trf.2018.02.033 [Accessed 12 September 2019].

Rivis, A., Abraham, C., and Snook, S., 2011. Understanding young and older male driver's willingness to drive while intoxicated: The predictive utility of constructs specified by the theory of planned behaviour and the prototype willingness model. British J ournal of Health Psychology [online], 16(2), 445456. Available from: https://doi.org/10.1348/135910710X522662 [Accessed 12 September 2019].

Road Safety Foundation, 2014. How Safe Are You on Britain's Roads? - EuroRAP 2014 results. (On file with author).

Rolison, M.R., and Scherman, A., 2003. College student risk-taking from three perspectives. Adolescence, 38(152), 689-704.

Schroeder, R.D., and Ford, J.A., 2012. Prescription drug misuse: A test of three competing criminological theories. Journal of Drug Issues [online], 42(1), 4-

27. Available from: https://doi.org/10.1177/0022042612436654 [Accessed 12 September 2019].

Schulz, S., 2017. A modern approach to the study of self-control and crime. Criminology in Europe [online], 16(3), 10-14. Available from: https://escnewsletter.org/newsletter/2017-3/modern-approach-study-selfcontrol-and-crime [Accessed 12 September 2019].

Steele, C.M., and Josephs, R.A., 1990. Alcohol myopia. Its prized and dangerous effects. American Psychologist [online], 45(8), 921-933. Available from: https://doi.org/10.1037//0003-066X.45.8.921 [Accessed 12 September 2019].

Stewart, K., and Sweedler, B.M., 1997. Driving Under the Influence of Alcohol. In: M. Plant, E. Single and T. Stockwell, eds. Alcohol: Minimising the Harm. What Works? London: Free Association Books, 126-142.

Unlock the Law, 2017. Drink Driving Law in Scotland [online]. Guide. Available from: https://www.unlockthelaw.co.uk/drink-driving-law-inscotland.html\#penalties [Accessed 30 J une 2019]. 
Weber, M., 1968. Economy and Society. New York: Bedminster Press.

Yeomans, H., 2014. Alcohol and Moral Regulation [online]. Bristol: Policy Press. Available from: https://doi.org/10.2307/j.ctt1t6p769 [Accessed 12 September 2019]. 


\section{Appendix}

\section{Questionnaire}

Tick box confirmation of participants' consent for the questionnaire to be used for research and teaching purposes:

1. You have been out and had a couple of alcoholic drinks. How likely is it you drive a car to get home?

2. You have just had a couple of alcoholic drinks, now you have to travel to work. How likely is it you drive a car?

3. You are taking a medication where you are not advised to drive. But now you need to get home. How likely is it you drive a car?

4. You are taking a medication where you are not advised to drive. Now you have to travel to work. How likely is it you drive a car?

Rated on a scale of 1-5: 1 very likely/ 2 likely/ 3 somewhat likely/ 4 not very likely/ 5 not at all likely, and an extra response "I don't know".

How much do you agree to the following statements about law generally?

1. One always has to follow the law.

2. It is better for society if everyone sticks to the law.

3. I try not to break legal rules.

4. Laws are usually made for good reason.

5. I trust that all aspects are considered and all opinions heard when a law is drafted.

6. I expect others to observe the law and so I myself need to observe the law.

7. In most cases it makes more sense to follow the law as this is what other people expect.

Rated on a scale running from " 1 " very, through to " 5 " not at all.

\section{How much do you agree to the following statements about driving?}

1. The roads have become dangerous.

2. Drivers need to be alert all the time.

3. Drivers who are tired cause more accidents.

4. Distraction causes a lot of accidents.

5. People on the roads do not always take care.

6. Roads are in good condition.**

7. There are a lot of unsafe vehicles on the roads.

Rated on a scale of 1-5: "1" very likely, through to " 5 " not at all likely

** Reverse coded: " 1 " not at all likely, through to " 5 " very likely.

1. How likely do you think it is that suspicious drivers are being stopped by police?

2. Imagine you are driving and there is a police control on the road ahead, how likely is it that you will be stopped?

Rated on a scale of 1-5: 1 very likely/ 2 likely/ 3 somewhat likely/ 4 not very likely/ 5 not at all likely, and an extra response, "I don't know".

\section{How much do you agree to the following statements about yourself?}

1. I often act on the spur of the moment without stopping to think.

2. I don't devote much thought and effort to preparing for the future.

3. I often do whatever brings me pleasure here and now, even at the cost of some distant goal.

4. I'm more concerned with what happens to me in the short run than in the long run.

5. I like to test myself every now and then by doing something a little risky.

6. Sometimes I will take a risk just for the fun of it. 
7. I sometimes find it exciting to do things for which I might get in trouble.

8. Excitement and adventure are more important to me than security.

Rated on a scale of 1-4: 1 strongly agree/ 2 agree somewhat/ 3 disagree somewhat/ 4 strongly disagree.

1. What is your age? $18-25 / 26-35 / 36-45 / 46-55 / 56-65 / 66-75 /$ over 75 .

2. What is your gender? Female/male.

3. Where do you live? In a rural area/in an urban area.

4. Do you have a responsibility to care for someone (e.g. your parents or children)? Yes/no.

5. Do you take medication that affects your driving? Yes, routinely/yes, occasionally/no/prefer not to say.

6. Do you have a driving licence? Yes/no.

7. How often do you drive? About 5 times a week/about 3 times a week/ once a week/fortnightly/monthly/never.

8. How often do you consume alcohol? About 5 times a week/about 3 times a week/once a week/fortnightly/monthly/never/prefer not to say.

9. Which country do you come from? UK/England/Wales/Scotland/Northern I reland/China/India/Pakistan/Poland Germany/Other (please state).

10. Other comments. 